\title{
ANALISIS PENDAPATAN USAHATANI DAN EFISIENSI PEMASARAN JAMUR MERANG (Volvariella volvacea)
}

\author{
FARM INCOME ANALYSIS AND MARKETING EFFICIENCY OF STRAW MUSHROOM \\ (Volvariella volvacea)
}

SUHAENI

Program Studi Agribisnis, Fakultas Pertanian Universitas Singaperbangsa Karawang, Karawang, Indonesia Email : suhaeni@faperta.unsika.ac.id

\begin{abstract}
The straw mushroom is one of the leading commodities in Karawang Regency. The growth of mushroom consumption always increases every year. Demand per day reaches 4-10 tons, while the supply only ranges from 4-7 tons. Thus, this commodity has the potential to increase the income of mushroom agribusiness actors. This study aims to analyze the income received by farmers, the pattern of marketing channels and marketing efficiency of straw mushrooms in Karawang Regency. The research method used was descriptive method with survey research techniques. The data used were primary and secondary data. The sample was determined in a nonprobabilistic way with the entry point being the main business actor (mushroom farmers), then forward and backward tracing was carried out using snowball sampling to obtain a sample at the next point. The analytical method used was the analysis of income, marketing margin, profit, farmer share and marketing efficiency. The results showed that there were 6 patterns of the straw mushroom marketing channels. The actors involved consist of farmers, traders, wholesalers, retailers and consumers. The results of the mushroom farming analysis showed that the $R / C$ value was 1.98 . The $R / C$ value $>1$ indicates that the business carried out by the mushroom farmers was feasible. Based on marketing margin, profit, farmers' share, and marketing efficiency, all marketing channels were categorized as efficient.
\end{abstract}

Keyword: straw mushroom, revenue, marketing channels, marketing efficiency

ABSTRAK

Jamur merang merupakan salah satu komoditas unggulan yang ada di Kabupaten Karawang. Pertumbuhan konsumsi jamur selalu meningkat setiap tahunnya. Permintaan per hari mencapai 4-10 ton, sementara penawarannya hanya berkisar 4-7 ton. Dengan demikian, komoditas ini sangat potensial untuk meningkatkan pendapatan pelaku agribisnis jamur merang. Penelitian ini bertujuan untuk menganalisis pendapatan yang diterima petani, pola saluran pemasaran dan efisiensi pemasaran jamur merang di Kabupaten Karawang. Metode penelitian yang digunakan adalah metode deskriptif dengan teknik penelitian survei. Data yang digunakan adalah data primer dan sekunder. Sampel ditentukan dengan cara non probabilistik dengan entry point adalah pelaku usaha utama (petani jamur), kemudian dilakukan penelusuran ke depan dan ke belakang (forward and backward) dengan menggunakan snowball sampling untuk mendapatkan sampel pada titik berikutnya. Metode Analisis yang digunakan adalah analisis pendapatan, marjin pemasaran, keuntungan, farmer share dan efisiensi pemasaran. Hasil penelitian menunjukkan bahwa terdapat 6 pola saluran pemasaran jamur merang. Pelaku yang terlibat terdiri dari petani, bandar, pedagang besar, pengecer dan konsumen. Hasil analisis usahatani jamur merang menunjukkan bahwa nilai $\mathrm{R} / \mathrm{C}$ sebesar 1,98. Nilai R/C >1 menunjukkan bahwa usaha yang dilakukan oleh petani jamur merang layak untuk diusahakan. Ditinjau dari marjin pemasaran, keuntungan, farmers's share, efisensi pemasaran, semua saluran pemasaran dikategorikan efisien.

Kata kunci: jamur merang, pendapatan, saluran pemasaran, efisiensi pemasaran

\section{PENDAHULUAN}

Komoditas hortikultura memiliki peranan penting dalam memberikan kontribusi terhadap Produk Domestik Bruto (PDB). Salah satu komoditas hortikultura yang memiliki pertumbuhan konsumsi cukup tinggi adalah komoditas jamur (Grimm \& Wösten, 2018). Jamur merupakan komoditas sayuran dengan pertumbuhan per kapita paling tinggi jika dibandingkan dengan komoditas sayuran lainnya. Jamur dikonsumsi tidak hanya untuk memenuhi kebutuhan gizi masyarakat tetapi juga untuk kesehatan (Pop et al., 2018) karena diperkaya dengan protein, fenolat, vitamin, antioksidan, dan mikro (Kora, 2020). Jamur mengandung 
fenolat dan antioksidan dapat digunakan sebagai obat (Al-Ghamdi et al., 2020) dan tujuan pengobatan (Abdel-Mawgoud et al., 2019). Sehingga selain sebagai makanan, jamur juga dapat dimanfaatkan sebagai obat (Ashraf et al., 2020) dan baik untuk diet karena rendah kalori, karbohidrat, lemak dan kolesterol (Fontes et al., 2019).

Rata-rata pertumbuhan konsumsi jamur di Indonesia pada tahun 2014 sebesar $8,7 \%$ meningkat menjadi $17,7 \%$ pada tahun 2018 (Badan Ketahanan Pangan, 2019). Permintaan (demand) terhadap jamur merang di Kabupaten Karawang per hari mencapai 410 ton, sementara penawaran (supply) hanya 4-7 ton per hari (BPS Kabupaten Karawang, 2018). Tingginya konsumsi jamur dapat memperluas lapangan kerja dan memberi peluang untuk berwirausaha.

Kabupaten Karawang menjadi salah satu kabupaten/kota yang memiliki produksi jamur tertinggi dibandingkan dengan sentra jamur lainnya. Urutan kedua penghasil jamur berturut-turut Bandung Barat, Bogor, Subang dan terkahir Cianjur (BPS Provinsi Jawa Barat, 2018). Jamur merang banyak dibudidayakan karena memiliki siklus hidup yang pendek yaitu kurang dari satu bulan (Munawar \& Kartika, 2017) dan usahatani jamur merang dinilai sangat menguntungkan (Fauziah \& Soejono, 2019). Namun, seiring berjalannya waktu produktivitas jamur merang khususnya di Kabupaten Karawang cenderung mengalami penurunan. Akumulatif produksi jamur dari empat Kecamatan sentra jamur di Kabupaten Karawang, yaitu Banyusari, Jatisari, Cilamaya Wetan dan Cilamaya Kulon dari tahun 2008 sampai dengan tahun 2018 selalu mengalami penurunan. Penyebab turunnya produktivitas jamur diantaranya adalah rendahnya kualitas bibit/benih jamur, teknik budidaya yang belum optimal, kurangnya manajemen usaha yang baik, rendahnya regenerasi sumber daya manusia dan belum terintegrasi dengan baik hubungan antara pelaku usaha.

Selain itu, petani jamur memiliki tantangan pemasaran domestik yang sangat kompetitif dengan jenis jamur lainnya seperti jamur tiram, kancing, kuping dan jenis jamur lainnya. Kemudian tantangan pemasaran dari eksternal, diantaranya adalah adanya jamur impor yang masuk dari Thailand, Jepang dan Cina dengan kemasan yang modern dan branding lux. Saat ini jamur impor sudah menguasai kurang lebih 30\% pasar modern di Indonesia.

Kendala pemasaran tersebut menjadi tantangan tersendiri bagi pelaku usaha. Apalagi selama ini pemasaran yang dilakukan oleh petani jamur merang masih dilakukan secara konvensional dan sangat tergantung kepada pedagang perantara. Bagian nilai yang diterima petani juga dianggap paling rendah jika dibandingkan dengan pelaku lainnya (Irianto \& Widiyanti, 2012). Kondisi ini menunjukkan adanya keterkaitan hubungan sosial yang terjadi antara petani jamur merang dengan pelaku lain yang terlibat dalam tatanan rantai pemasaran tersebut. Penelitian ini bertujuan untuk megukur pendapatan usahatani jamur merang, mengetahui pola saluran pemasaran jamur merang dan mengukur tingkat efisiensi pemasaran jamur merang di Kabupaten Karawang.

\section{METODE PENELITIAN}

Metode penelitian yang digunakan adalah metode deskriptif. Teknik pengumpulan data dilakukan dengan survei, wawancara dan penyebaran kuesioner kepada responden. Jumlah responden penelitian ini adalah 54 petani jamur merang diambil secara random sampling dan 16 pedagang diambil secara snowball sampling. Lokasi penelitian di sentra jamur merang yaitu Kecamatan Jatisari, Kabupaten Karawang. Penentuan lokasi dilakukan secara purposive sampling, dengan pertimbangan lokasi penelitian adalah sentra jamur merang. Variabel penelitian yang digunakan adalah pendapatan usahatani jamur merang dan efisiensi pemasaran mulai dari petani, bandar, pedagang besar, pengecer dan konsumen. Metode analisis yang digunakan dalam penelitian ini adalah analisis pendapatan, marjin pemasaran, profit marjin, farmer share dan efisiensi pemasaran.

Menurut (Sukirno, 2002), biaya produksi dan pendapatan dapat dihitung dengan menggunakan rumus:

$$
T R=P x Q
$$

dimana:

$\mathrm{TR}=$ total Revenue (total penerimaan) 
$\mathrm{P} \quad=$ price $($ harga $)$

$\mathrm{Q}=$ quantity (jumlah produksi)

Total Biaya ditentukan dengan menggunakan rumus:

$$
T C=T F C+T V C
$$

dimana:

$\mathrm{TC}=$ total cost (total biaya)

$\mathrm{TFC}=$ total fix cost (total biaya tetap)

$\mathrm{TVC}=$ total variable cost (total biaya variabel)

Pendapatan ditentukan dengan menggunakan rumus sebagai berikut:

$$
I=T R-T C
$$

dimana:

I $\quad=$ income (pendapatan)

$\mathrm{TR}=$ total revenue (total penerimaan)

$\mathrm{TC}=$ total cost (biaya total)

Metode pendekatan yang digunkaan untuk perhitungan layak atau tidaknya usahatani dapat dilakukan dengan menghitung Revenue cost (RC) Ratio, Benefit Cost (B/C) Ratio dengan rumus (Hanafi, 2010):

$$
R C \text { ratio }=\frac{\text { Penerimaan }}{\text { Biaya Produksi }}
$$

Kriteria yang digunkan:

$\mathrm{R} / \mathrm{C}$ ratio > 1, maka usahatani layak diusahakan

$\mathrm{R} / \mathrm{C}$ ratio $<1$, maka usahatani tidak layak diusahakan

$\mathrm{R} / \mathrm{C}$ ratio $=1$, maka usahatani dikatakan inpas, tidak memberikan keuntungan dan kerugian dalam analisis kelayakan dikatakan tidak layak.

Menurut (Wahyu Andayani, 2007), penentukkan tingkat efisiensi pemasaran dapat menggunakan beberapa variabel, yaitu margin keuntungan (profit margin), marjin pemasaran (marketing margin), dan bagian petani (farmer share) dan efisiensi pemasaran.

\section{Marjin Pemasaran (Profit Margin)}

Marjin pemasaran (Mp) adalah selisih harga produk ditingkat konsumen (Pr) dengan harga ditingkat produsen (Pf) atau penjumlahan biaya pada tiap lembaga pemasaran (bi) dengan parameter keuntungan masing-masing (ki).

dimana:

$$
M p=P r-P f \text { atau } M p=\sum b i+\sum k i
$$

$\mathrm{Mp}=$ Marjin pemasaran

$\operatorname{Pr} \quad=$ Harga di tingkat konsumen (user)

Pf = Harga di tingkat produsen (farm)

bi = Biaya tata niaga ke-i

ki = keuntungan ke-i

Suatu sistem distribusi pemasaran dikatakan efisien jika besarnya tingkat marjin pemasaran bernilai kurang dari $50 \%$ dari tingkat harga yang di bayarkan konsumen.

2. Marjin Keuntungan

Keuntungan adalah selisih harga yang dibayarkan konsumen (rata-rata) dengan biaya pemasaran.

Mki $=($ Harga jual $)-\{($ harga beli $)+($ biaya $)\}$ dimana:

Mki = Keuntungan

Semakin besar marjin pemasaran maka makin tidak efisien sistem pemasaran tersebut (Hanfie, 2010).

\section{Petani (Farmer Share)}

Menurut (Soekartawi, 2005), share harga yang diterima Petani (SPf) adalah besarnya bagian yang diterima petani dari harga yang dibayar konsumen atas suatu produk yang dinyatakan dalam persen.

dimana:

$$
S P f=\frac{P f}{P r} \times 100 \%
$$

SPf = Share harga di tingkat petani

Pr = Harga di tingkat konsumen (user)

Pf = Harga di tingkat petani $($ farm $)$

4. Efisiensi Pemasaran

Menurut (Downey, 1992), Efisiensi pemasaran dapat dihitung dengan menggunakan rumus efisiensi pemasaran (Ep) sebagai berikut:

Ef isiensi Pemasaran $=\frac{\text { Biaya Pemasaran }}{\text { Nilai Produk yang dipasarkan }}$

Kaidah Keputusan:

1. Ep $>1$ berarti tidak efisien

2. Ep $<1$ berarti efisien 


\section{HASIL DAN PEMBAHASAN}

\section{Gambaran dan Pendapatan Usahatani Jamur Merang}

Kabupaten Karawang merupakan salah satu Kabupaten di Jawa Barat yang memiliki potensi tinggi dalam bidang pertanian. Secara geografis kabupaten Karawang terletak $107^{0}$ $02^{\prime}-107^{0} 40^{\prime} \mathrm{BT}$ dan $5^{0} 56^{\prime}-6^{0} 34^{\prime}$ LS. Karawang termasuk daerah dataran yang relative rendah dengan variasi ketinggian wilayah antara 0-1279 meter di atas permukaan laut dengan tingkat kemiringan wilayah $0-2 \%, 2-15 \%, 15-40 \%$ dan di atas $40 \%$ dengan suhu rata-rata $27^{\circ} \mathrm{C}$. Kabupaten Karawang selain dikenal sebagai lumbung padi, juga terkenal dengan sentra jamur merangnya (Munawar \& Kartika, 2017).

Kecamatan Jatisari merupakan salah satu daaerah sentra jamur merang di Kabupaten Karawang. kecamatan ini sudah terkenal sebagai pemasok jamur di pasar lokal maupun pasar luar Kabupaten Karawang. Potensinya sangat besar. Jamur merang yang dihasilkan mampu bersaing dengan produk jamur merang dari Kabupaten lain yang ada di Jawa Barat, bahkan di luar Jawa.

Salah satu pelaku pembudidaya jamur merang di Kecamatan Jatisari adalah Gabungan kelompok tani (Gapoktan) Saluyu, yang diketuai oleh Bapak H. Sulaeman. Usahatani jamur merang ini sudah dilakukan sejak tahun 1987 sampai sekarang. Sumbersumber bahan baku dalam proses produksi seperti jerami, kapas, dedak (bekatul), kapur, dan bibit jamur merupakan bahan baku utama. Selain itu, membutuhkan barang material seperti bambu tali, paku dan plastic Fe. Bahkan saat ini material bangunan fisik kubung menggunakan baja ringan sebagai bahan baku fisik bangunan. Bahan baku produksi serta sarana lainnya sangat mudah untuk didapatkan.

Air dibutuhkan dalam proses permentasi bahan baku jerami, kapas dan untuk penyiraman maupun pasteurisasi yang merupakan bagian sangat penting dari proses produksi jamur merang. Kondisi air tersedia dengan aman dan baik. Namun demikian, terkadang kualitas air jelek dan banjir. Sehingga berdampak terhadap produktivitas dan kualitas jamur merang yang dihasilkan.
Dalam pelaksanaan budidaya jamur merang sesungguhnya tidak membutuhkan lahan yang luas. Minimal ukuran $50 \mathrm{~m}^{2}$ bisa dilakukan budidaya jamur merang untuk satu unit kubung jamur merang. Secara spesifik budidaya jamur merang membutuhkan suhu ruang dalam kubung maksimal $37^{\circ} \mathrm{C}$ dan minimal $30^{\circ} \mathrm{C}$ dan humidity $20 \%$ s/d $85 \%$. Suhu tersebut sangat sesuai dengan cuaca dan iklim Kabupaten Karawang.

Banyak keuntungan yang dirasakan oleh pelaku agribisnis jamur merang, khususnya yang dirasakan oleh anggota kelompok tani, diantaranya adalah dapat meningkatkan pendapatan petani, menambah lapangan kerja baru, menambah gizi keluarga, memanfaatkan limbah-limbah pertanian yang sudah tidak terpakai atau terbuang, bekas/limbah budidaya jamur merang bisa digunakan untuk kompos/pupuk palawija dan sayuran serta tidak memerlukan lahan yang luas.

Ada beberapa tahap perlakuan dalam budidaya jamur merang diantaranya adalah tahap pengomposan jerami dan kapas, tahap memasukan kompos jerami dan kapas ke dalam lumbung, tahap melakukan stim dan memasang bibit jamur dan panen. Untuk mengetahui kapan jamur merang dapat dipanen, maka harus diketahui terlebih dahulu berapa lama proses pembuatan jamur merang itu sendiri, yaitu antara lain:

- Proses pengomposan bahan baku: 7 hari

- Masa tanam sampai siap panen : 9 hari

- Lamanya panen dari awal-akhir : 12 hari

Proses pembuatan jamur merang sampai dengan selesai panen memakan waktu selama 23 hari. Dalam proses pemanenan jamur merang harus dilakukan dengan hatihati, agar jamur merang yang masih kecilkecil tidak ikut tercabut. Panen bisa dilakukan sebanyak 12 kali. Rata-rata produksi jamur merang dalam satu kali musim panen adalah $225 \mathrm{~kg}$. Jumlah ini menurun jika dibandingkan dengan tahuntahun sebelumnya yang bisa mencapai 300$400 \mathrm{~kg}$ dalam satu kali musim panen. Salah satu faktor yang menyebabkannya adalah kualitas bibit jamur merang. Petani jamur 
merang di Kecamatan Jatisari belum mampu menghasilkan jamur merang yang berkualitas dan tersertifikasi. Bibit jamur diperoleh dari toko agroinput yang ada di Karawang atau membeli langsung dari kota Jogjakarta.

Tabel 1. Menunjukkan rata-rata hasil panen jamur merang dalam satu kali musim panen dalam satu kumbung jamur berukuran
$7 \times 4$ meter. Hasil analisis pendapatan usahatani jamur merang menunjukkan bahwa nilai $\mathrm{R} / \mathrm{C}$ ratio sebesar 1,98 yang menunjukkan bahwa setiap Rp. 1 biaya yang dikeluakan akan menambahkan penerimaan sebesar Rp 1,98. Nilai R/C >1 menunjukkan bahwa usaha yang dilakukan oleh petani jamur merang layak untuk diusahakan.

Tabel 1. Analisis Pendapatan Usahatani Jamur Merang Dalam Satu Kali Panen Per Kumbung (7x4 m)

\begin{tabular}{|c|c|c|c|c|c|}
\hline No & Uraian & Jumlah & Satuan & Harga rata-rata & Nilai (Rp) \\
\hline $\mathrm{A}$ & Biaya variable & & & & \\
\hline 1 & Bibit (kg) & 50 & bungkus & 4.000 & 200.000 \\
\hline 2 & Kapas & 200 & $\mathrm{Kg}$ & 1.000 & 200.000 \\
\hline 3 & Jerami & 3 & Colt & 350.000 & 1.050 .000 \\
\hline 4 & Kayu bakar & 2 & Kubik & 200.000 & 400.000 \\
\hline 5 & Dedak & 160 & $\mathrm{Kg}$ & 3.000 & 480.000 \\
\hline 6 & Kapur & 1 & karung & 75.000 & 75.000 \\
\hline 7 & Tenaga kerja langsung & 1 & Orang & 600.000 & 600.000 \\
\hline \multicolumn{5}{|c|}{ Jumlah biaya variable } & 3.005 .000 \\
\hline B & Biaya Penyusutan Tetap & & & & \\
\hline 1 & Kumbung jamur & 1 & Kumbung & 335.000 & 335.000 \\
\hline 2 & Selang air & 1 & Buah & 8.500 & 8.500 \\
\hline 3 & Timbnagan & 1 & Buah & 4.500 & 4.500 \\
\hline 4 & Pisau & 1 & Buah & 2.000 & 2.000 \\
\hline 5 & Keranjang & 1 & Buah & 1.000 & 1.000 \\
\hline 6 & Pompa air & 1 & Buah & 17.000 & 17.000 \\
\hline 7 & $\begin{array}{l}\text { Alat pembersih Kumbung } \\
\text { Jamur }\end{array}$ & 1 & & 2.500 & 2.500 \\
\hline 8 & Serokan & 1 & Buah & 2.500 & 2.500 \\
\hline 9 & Terpal & 1 & Buah & 2.000 & 2.000 \\
\hline 10 & Drum & 1 & Buah & 27.500 & 27.500 \\
\hline \multicolumn{2}{|c|}{ Jumlah biaya tetap } & & & & 402.500 \\
\hline \multirow{2}{*}{\multicolumn{2}{|c|}{$\begin{array}{l}\text { Total Biaya produksi } \\
\text { Total Penerimaan }\end{array}$}} & & & & 3.407500 \\
\hline & & 225 & $\mathrm{Kg}$ & 30.000 & 6.750 .000 \\
\hline \multicolumn{2}{|c|}{ Total Pendapatan } & & & & 3.342 .500 \\
\hline \multicolumn{2}{|c|}{$\mathrm{R} / \mathrm{C}$} & & & & 1,98 \\
\hline
\end{tabular}

Sumber: Analisis data primer, 2020

Berdasarkan hasil penelitian di lapangan, permasalahan dalam agribisnis jamur merang adalah petani/produsen jamur merang belum bisa menyediakan supply jamur merang sesuai dengan permintaan pasar. Hal tersebut diakibatkan produksi yang semakin menurun. Faktor-faktor yang menyebabkan turunnya produksi adalah sulitnya pengadaan bibit jamur merang yang berkualitas dan ketebalan media tanam (Riduwan et al., 2013) akibat sulitnya pengadaan jerami, sulitnya modal untuk usahatani (Melani et al., 2021). Selain itu, dalam aspek pemasaran petani jamur masih sangat tergantung terhadap bandar akibat kurangnya infromasi pasar dan harga.
Dengan demikian, sangat diperlukan perbaikan saluran pemasaran yang mampu memberikan keberadilan bagi setiap pelakunya.

\section{Saluran Pemasaran Jamur Merang}

Pada pola saluran pemasaran jamur merang terdapat empat komponen utama yaitu produk, pelaku, kegiatan dan input (Gambar 1). Produk yang dimaksud pada gambar merupakan jamur merang yang diproduksi oleh produsen untuk dikirim ke konsumen. Jamur merang mudah rusak dan tidak tahan lama. Kesegaran produk merupakan tolak ukur kualitas pemasaran. Sebab, semakin lama pola pemasarannya, 
semakin rendah kualitas kesegarannya. Terdapat enam pola saluran pemasaran jamur merang yang melibatkan lima pelaku yaitu, petani, bandar, pedagang besar, pengecer dan konsumen.

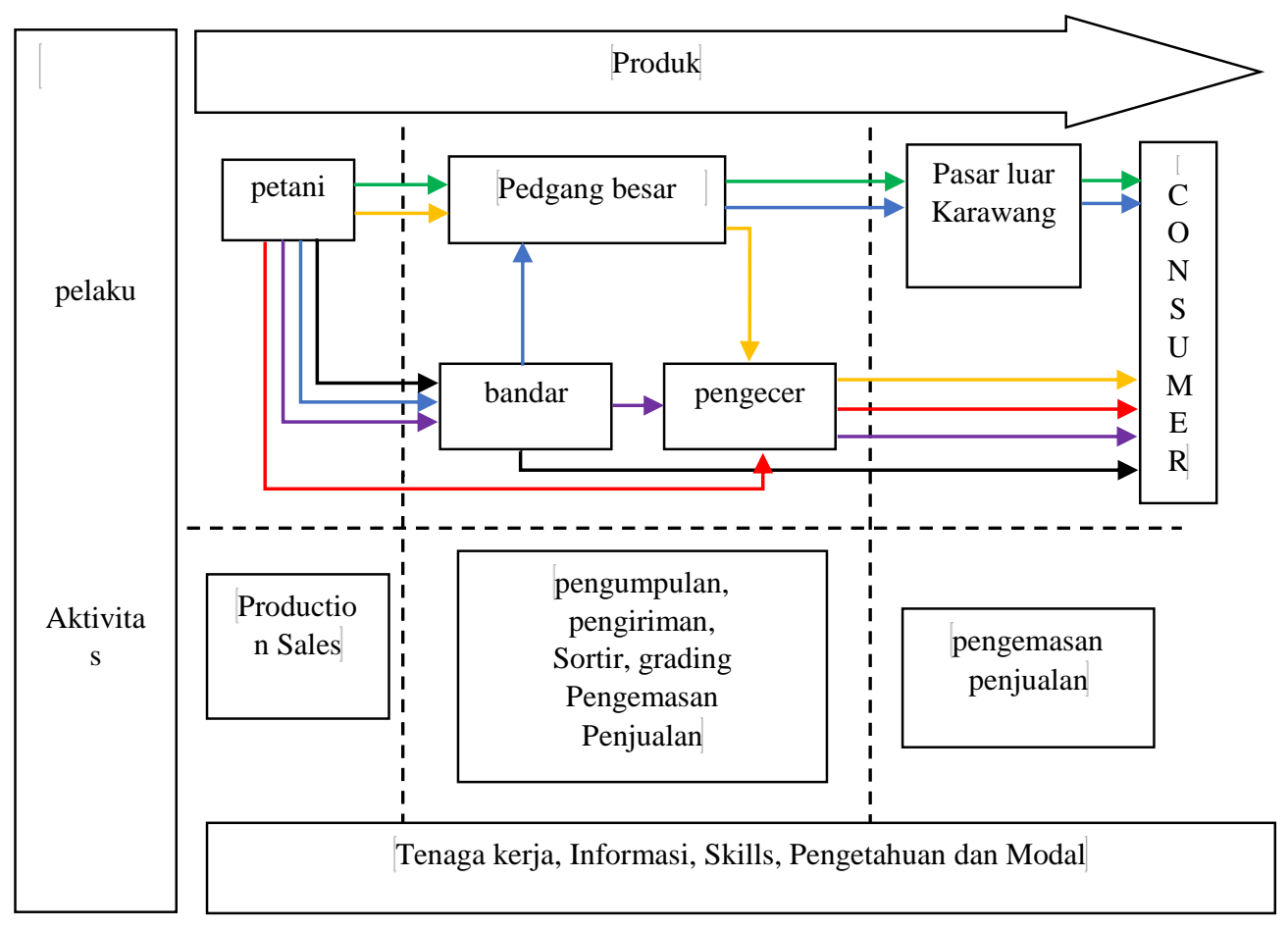

Gambar 1. Saluran Pemasaran Jamur Merang

\section{Efisiensi Pemasaran}

Tabel 2. Menunjukkan nilai marjin pemasaran di setiap pola saluran pemasaran nilainya kurang dari $50 \%$ dari harga yang dibayarkan konsumen. Hal ini menunjukan saluran pemasaran dinilai sudah efisien. Tinggi rendahnya marjin pemasaran dipakai untuk mengukur efisiensi sistem pemasaran. Semakin tinggi marjin pemasaran maka makin tidak efisien sistem pemasaran tersebut. Marjin pemasaran semakin tinggi akibat bagian yang diterima petani produsen (farmer's share) menjadi kecil. Hal ini sangat tidak menggairahkan produsen untuk berproduksi. Selain itu, marjin pemasaran akan semakin bertambah jika semakin banyak lembaga pemasaran yang terlibat, dengan demikian semakin panjang saluran pemasarannya maka semakin besar marjinnya, sehinggga menyebabkan harga di tingkat konsumen akan lebih mahal.

Profit marjin merupakan selisih harga yang dipasarkan ke produsen dengan harga yang diberikan oleh konsumen dikurangi dengan biaya-biaya pemasaran. Jarak antara tempat produksi pertanian dari produsen ke konsumen menyebabkan terjadinya perbedaan besarnya biaya dan keuntungan. Perbedaan harga di masing-masing lembaga pemasaran sangat bervariasi tergantung besar kecilnya keuntungan yang diambil oleh masing-masing lembaga pemasaran. Profit marjin bisa juga digunakan untuk melihat saluran pemasaran yang paling sesuai dan memberikan keadilan per kg jamur merang di setiap saluran pemasaran. Berdasarkan hasil analisis diperoleh profit marjin terkecil adalah bandar sebesar Rp. 2.083 dan Rp 2.018 (pola 4 dan 5). Hal tersebut dikarenakan cukup panjangnya rantai saluran pemasaran, sehingga keuntungan yang diambil Bandar hanya sedikit, selain itu pula karena adanya biaya pemasaran misalnya biaya pengangkutan dan transportasi. Meskipun keuntungan Bandar kecil (pada pola 4 dan 5), Bandar membeli hasil panen 
petani dalam jumlah banyak. Profit marjin lembaga pemasaran yang tertinggi juga adalah pengecer sebesar Rp. 5.500 per $\mathrm{kg}$ jamur merang (pola 5). Keuntungan cukup tinggi namun kunatitas pembelian terbatas.

Tabel 2. Hasil Analisis Marjin Pemasaran, Profit Marjin, Farmer's share dan Efisiensi Pemasaran Jamur Merang di kabupaten Karawang

\begin{tabular}{|c|c|c|c|c|c|c|c|c|}
\hline \multirow{2}{*}{$\begin{array}{l}\text { Pola } \\
\text { saluran }\end{array}$} & \multicolumn{6}{|c|}{ Harga, Biaya, Marjin (Rp) } & \multirow{2}{*}{$\begin{array}{l}\text { Farmer's } \\
\text { Share }\end{array}$} & \multirow{2}{*}{$\begin{array}{l}\text { Efisiensi } \\
\text { Pemasaran }\end{array}$} \\
\hline & Produksi & Pembelian & Penjualan & $\begin{array}{l}\text { Biaya } \\
\text { Pemasaran }\end{array}$ & $\begin{array}{l}\text { Profit } \\
\text { Marjin }\end{array}$ & $\begin{array}{l}\text { Marjin } \\
\text { Pemasaran }\end{array}$ & & \\
\hline $\begin{array}{l}\text { Pola 1: } \\
\text { Petani }\end{array}$ & 14.855 & & 27.000 & & 12.145 & & $81,8 \%$ & 0,05 \\
\hline $\begin{array}{l}\text { Pedagang } \\
\text { besar }\end{array}$ & & 27.000 & 33.000 & 1.773 & 4.227 & 6.000 & & \\
\hline $\begin{array}{l}\text { Pasar luar } \\
\text { daerah }\end{array}$ & & 33.000 & & & & & & \\
\hline $\begin{array}{l}\text { Pola 2: } \\
\text { Petani }\end{array}$ & 855 & & 27000 & & 12145 & & $71 \%$ & 006 \\
\hline $\begin{array}{l}\text { Pedagang } \\
\text { besar }\end{array}$ & & 27.000 & 33.000 & 1.322 & 4.678 & 6.000 & & \\
\hline $\begin{array}{l}\text { Pengecer } \\
\text { lokal }\end{array}$ & & 33.000 & 38.000 & 833 & 4.167 & 5.000 & & \\
\hline $\begin{array}{l}\text { Konsumen } \\
\text { lokal }\end{array}$ & & 38.000 & & & & & & \\
\hline $\begin{array}{l}\text { Pola 3: } \\
\text { Petani }\end{array}$ & 14.855 & & 30.000 & & 12.145 & & $83,3 \%$ & 0,05 \\
\hline $\begin{array}{l}\text { Bandar } \\
\text { Konsumen } \\
\text { lokal }\end{array}$ & & $\begin{array}{l}30.000 \\
36.000\end{array}$ & 36.000 & 1.667 & 4.333 & 6.000 & & \\
\hline $\begin{array}{l}\text { Pola 4: } \\
\text { Petani }\end{array}$ & 14.855 & & 27.000 & & 12.145 & & $75 \%$ & 0,08 \\
\hline Bandar & & 27.000 & 30.000 & 917 & 2.083 & 3.000 & & \\
\hline $\begin{array}{l}\text { Pedagang } \\
\text { besar }\end{array}$ & & 30.000 & 36.000 & 1.983 & 4.017 & 6.000 & & \\
\hline $\begin{array}{l}\text { Pasar luar } \\
\text { daerah } \\
\text { Pola 5: }\end{array}$ & & 36.000 & & & & & & \\
\hline Petani & 14.855 & & 30.000 & & 12.145 & & $75 \%$ & 0,06 \\
\hline Bandar & & 30.000 & 33.000 & 982 & 2.018 & 3.000 & & \\
\hline Pengecer & & 33.000 & 40.000 & 1.500 & 5.500 & 7.000 & & \\
\hline $\begin{array}{l}\text { Konsumen } \\
\text { lokal }\end{array}$ & & 40.000 & & & & & & \\
\hline $\begin{array}{l}\text { Pola 6: } \\
\text { Petani }\end{array}$ & 14.855 & & 33.000 & & 12.145 & & $86 \%$ & 0,03 \\
\hline Pengecer & & 33.000 & 38.000 & 1.000 & 4.000 & 5.000 & & \\
\hline $\begin{array}{l}\text { Kosumen } \\
\text { lokal }\end{array}$ & & 38.000 & & & & & & \\
\hline
\end{tabular}

Sumber: Analisis data primer, 2020

Berdasarkan hasil wawancara yang mendalam bersama petani jamur merang, menunjukkan bahwa petani memiliki ketergantungan yang sangat tinggi terhadap bandar terutama dalam pengadaan biaya. Akses petani terhadap Lembaga keuangan seperti Bank masih sangat terbatas. Petani diberikan pinjaman modal oleh bandar/pedagang besar, lalu petani akan menjual hasil panennya kepada bandar tersebut. Akses petani ke pasar tradisional maupun pasar induk apalagi pasar modern dinilai terbatas, sehingga masih sangat tergantung terhadap Bandar. Terbukti volume penjualan hasil panen yang dijual kepada bandar sebanyak $70 \%$, sementara sisanya 
sebanyak $30 \%$ petani kirim ke pedagang besar dan pengecer di pasar tradisional. Keterbatasan modal dan teknologi juga mengakibatkan petani memiliki posisi tawar yang rendah dalam proses negosiasi dengan pihak perantara.

Farmer's share merupakan persentase perbandingan antara harga di tingkat petani dan harga di tingkat konsumen akhir. Nilai farmer's share pada rantai saluran pemasaran berkisar $71 \%-86 \%$. Nilai farmer's share dari enam pola saluran pemasaran cukup tinggi. Menurut (Rosmawati, 2011), semakin tinggi tingkat persentase farmer's share maka semakin efisien kegiatan pemasaran yang dilakukan dan sebaliknya semakin rendah tingkat persentase farmer's share maka akan semakin rendah pula tingkat efisiensi dalam kegiatan pemasaran.

Efisiensi pemasaran dilihat dengan membandingkan antara biaya pemasaran dengan nilai produk yang dipasarkan. Berdasarkan hasil analisa diperoleh nilai efisiensi pemasaran rantai saluran pemasaran jamur merang di Kabupaten Karawang berkisar 0,03-0,08. Menurut (Downey, 1992), suatu saluran pemasaran akan dinilai efisien jika nilai efisiensi $<1$ dan dinilai tidak efisien jika nilai efisiensi $>1$, Jika melihat nilai efisiensi pada tiap pola saluran pemasaran jamur merang tersebut, maka seluruh pola saluran pemasaran tersebut dikategorikan efisien.

\section{KESIMPULAN}

Terdapat 6 pola saluran pemasaran jamur merang. Pelaku yang terlibat terdiri dari petani, bandar, pedagang besar, pengecer dan konsumen. Hasil analisis pendapatan usahatani jamur merang menunjukkan bahwa nilai $\mathrm{R} / \mathrm{C}$ sebesar 1,98. Nilai $\mathrm{R} / \mathrm{C} \quad>1$ menunjukkan bahwa usaha yang dilakukan oleh petani jamur merang layak untuk diusahakan. Ditinjau dari marjin pemasaran, keuntungan, farmers's share, efisensi pemasaran, semua saluran pemasaran dikategorikan efisien.

\section{DAFTAR PUSTAKA}

ABDEL-MAWGOUD, M., KHEDR, F. G., \& MOHAMMED, E. I. (2019). Phenolic Compounds, Antioxidant and Antibacterial Activities of Rhus flexicaulis Baker. In Jordan Journal of Biological Sciences (Vol. 12, Issue 1).

AL-GHAMDI, A. Y., FADLELMULA, A. A., \& ABDALLA, M. O. M. (2020). Total Phenolic Content, Antioxidant and Antimicrobial Activity of Ruta chalepensis L. Leaf Extract in Al-Baha Area, Saudi Arabia. In Jordan Journal of Biological Sciences (Vol. 13).

ASHRAF, S. A., ELKHALIFA, A. E. O., SIDDIQUI, A. J., PATEL, M., AWADELKAREEM, A. M., SNOUSSI, M., SNOUSSI, M., ASHRAF, M. S., ADNAN, M., \& HADI, S. (2020). Cordycepin for Health and Wellbeing: A Potent Bioactive Metabolite of an Entomopathogenic Medicinal Fungus Cordyceps with Its Nutraceutical and Therapeutic Potential. Molecules, 25(12).

https://doi.org/10.3390/molecules 25122 735

BADAN KETAHANAN PANGAN. (2019). Statistik Ketahanan Pangan 2018. Badan Ketahanan Pangan Kementerian Pertanian.

BPS KABUPATEN KARAWANG. (2018). Kabupaten Karawang Dalam Angka 2018. BPS Kabupaten Karawang.

BPS PROVINSI JAWA BARAT. (2018). Provinsi Jawa Barat Dalam Angka 2018. BPS Provinsi Jawa Barat, 721. https://jabar.bps.go.id/publication/2018/ 08/16/d8b96de222796402938666e4/pro vinsi-jawa-barat-dalam-angka2018.html

DOWNEY, W. . DAN S. P. E. (1992). Manajemen Agribisnis. Erlangga.

FAUZIAH, F. R., \& SOEJONO, D. (2019). Analisis Pendapatan Usahatani Jamur Merang dan Kontribusinya Terhadap Pendaatan Rumah Tangga Petani di Kelurahan Sempusari Kecmatan Kaliwates Kabupaten Jember. SEPA: Jurnal Sosial Ekonomi Pertanian Dan Agribisnis, $15(2), \quad 172$. https://doi.org/10.20961/sepa.v15i2.264 
92

FONTES, A., ALEMANY-PAGÈS, M., OLIVEIRA, P. J., RAMALHOSANTOS, J., ZISCHKA, H., \& AZUL, A. M. (2019). Antioxidant versus proapoptotic effects of mushroom-enriched diets on mitochondria in liver disease. In International Journal of Molecular Sciences (Vol. 20, Issue 16). MDPI AG. https://doi.org/10.3390/ijms20163987

GRIMM, D., \& WÖSTEN, H. A. B. (2018). Mushroom cultivation in the circular economy. In Applied Microbiology and Biotechnology (Vol. 102, Issue 18, pp. 7795-7803). Springer Verlag. https://doi.org/10.1007/s00253-0189226-8

HANAFI, R. (2010). Pengantar Ekonomi Pertanian. ANDI.

IRIANTO, H., \& WIDIYANTI, E. (2012). Analysis of Value Chain and Marketing Efficiency Mushroom Agribusiness in Karanganyar District. Sepa, 9(2), 260272.

KORA, A. J. (2020). Nutritional and antioxidant significance of seleniumenriched mushrooms. Bulletin of the National Research Centre, 44(1). https://doi.org/10.1186/s42269-02000289-w

MELANI, S. S., SULISTYOWATI, L., \& LUCIANA, T. (2021). Sumber Risiko Dan Mitigasi Risiko Jamur Merang ( Volvariella Volvaceae ) Di Kecamatan Jatisari Kabupaten Karawang Sources Of Risk And Risk Mitigation Of Merang Mushroom (Volvariella volvaceae) In Jatisari District, Karawang Regency Siti Sarah Melani *. 7(2), 1756-1769.

MUNAWAR, F. R., \& KARTIKA, J. G. (2017). Produksi dan Kualitas Jamur Merang (Volvariella volvaceae) pada Kelompok Tani "Mitra Usaha" Kabupaten Karawang. Bul. Agrohorti, 5(264-273).

https://journal.ipb.ac.id/index.php/bulag ron/article/view/16807/12243

POP, R. M., PUIA, I. C., PUIA, A., CHEDEA, V. S., LEOPOLD, N., BOCSAN, I. C., \& BUZOIANU, A. D. (2018). Characterization of Trametes versicolor: Medicinal mushroom with important health benefits. Notulae Botanicae Horti Agrobotanici ClujNapoca, $\quad 46(2), \quad 343-349$. https://doi.org/10.15835/nbha46211132

RIDUWAN, M., HARIYONO, D., NAWAWI, M., BUDIDAYA, J., \& PERTANIAN, P. F. (2013). Pertumbuhan dan hasil jamur merang (volvariella volvacea) pada berbagai sistem penebaran bibit dan ketebalan media. Jurnal Produksi Tanaman, 1(1), 70-79.

https://media.neliti.com/media/publicati ons/125744-ID-pertumbuhan-dan-hasiljamur-merang-volva.pdf

Rosmawati, H. (2011). Analisis Efisiensi Pemasaran Pisang Produksi Petani di Kecamatan Lengkiti Kabupaten Ogan Komering Ulu. Agronobis, 3(5), 1-9.

Soekartawi. (2005). Prinsip Dasar -Hasil Pertanian Teori dan Aplikasinya. Grafindo Persada.

Sukirno, S. (2002). Pengantar Teori Mikroekonomi. PT. Raja Grafindo Persada.

Wahyu Andayani. (2007). Analisis Efisiensi Pemasaran Kacang Mete (Cashew Nuts) Di Kabupaten Wonogiri. Akta Agrosia, 7(1). http://katalog.pustaka.unand.ac.id//inde x.php?p=show_detail\&id=90084 